\title{
Beneficial effect of carbon nanotubes on the performances of Nafion membranes in fuel cell applications
}

\author{
Jean-Michel Thomassin ${ }^{\mathrm{a},}$, Jozef Kollar ${ }^{\mathrm{a}}$, Giuseppe Caldarella ${ }^{\mathrm{b}}$, Albert Germain ${ }^{\mathrm{b}}$, Robert Jérôme ${ }^{\mathrm{a},}$, Christophe \\ Detrembleur $^{\mathrm{a}}$ \\ ${ }^{a}$ Center for Education and Research on Macromolecules (CERM), University of Liège, Sart-Tilman, B6, B-4000 \\ Liège, Belgium \\ ${ }^{b}$ Laboratoire de Chimie Industrielle, Institut de Chimie B6, University of Liège, Sart-Tilman, B-4000 Liège, \\ Belgium
}

\begin{abstract}
Multi-walled carbon nanotubes (MWCNTs) were dispersed by melt-extrusion within Nafion® membranes in order to decrease the methanol permeability without deleterious effect on the ionic conductivity. The risk of short-circuits was minimized by keeping the carbon nanotubes content lower than the percolation threshold. Two series of carbon nanotubes grafted by carboxylic acid groups were used, i.e., commercially available carbon nanotubes and MWCNTs home-grafted by carboxylic acid containing alkyl radicals. The second series of nanotubes were more resistant to break-up during melt-processing. Methanol permeability was decreased by approximately $60 \%$ without any decrease in the ionic conductivity. In parallel, the Young's modulus was increased by $140 \%$ and $160 \%$ as compared to pure Nafion® at MWCNT contents of 1 and 2 wt $\%$, respectively.
\end{abstract}

Keywords: Fuel cell - Membrane - Carbon nanotubes - Nafion

\section{INTRODUCTION}

Direct methanol fuel cell (DMFC) is a possible option for electricity generation because of a high energy density and simplicity of operation compared to systems including a reformer for the production of hydrogen from liquid fuel. The DMFC technology relies on fuel cells equipped with a proton exchange membrane (PEMFC), that plays the role of the electrolyte. Most commercially available proton exchange membranes are fluorinated ionomers, such as Nafion ${ }^{\circledR}$ produced by DuPont. However, the high cost, low conductivity at low humidity and/or high temperature $\left(>100^{\circ} \mathrm{C}\right)$, loss of mechanical stability at high temperature $\left(>130^{\circ} \mathrm{C}\right)$ and high methanol crossover are the major drawbacks of these perfluoropolymers.

These problems must be overcome because a high methanol cross-over decreases not only the fuel efficiency, but also the cathode performance. Solid electrolyte membranes with a high proton conductivity $(>0.01 \mathrm{~S} / \mathrm{cm})$ with little or no dependence on humidity above $100^{\circ} \mathrm{C}$ and with stable mechanical properties at high temperature are thus very desirable. Indeed, operation at elevated temperatures improves the kinetics of the electrode reactions and the $\mathrm{CO}$ tolerance of the electrocatalysts.

Two strategies are commonly used for tackling these problems. The first one consists in replacing Nafion ${ }^{\circledR}$ by alternative polymers, such as sulfonated polyetherketone [1,2], sulfonated polysulfone [3-5], sulfonated aromatic polyimide [6, 7] and polybenzimidazole (PBI) doped by a strong acid, e.g., $\mathrm{H}_{3} \mathrm{PO}_{4}$ and $\mathrm{H}_{2} \mathrm{SO}_{4}$ [8-10]. PBI membranes are remarkable because they do not need to be humidified for exhibiting high ionic conductivity, which allows for operation at temperature higher than $100^{\circ} \mathrm{C}$. The second strategy relies on the modification of ion-conducting polymers by inorganic fillers, such as silica [11, 12], heteropolyacid [13, 14], zirconium phosphate [15-17] and multi-layered silicates (montmorillonite) [18-24]. The main reason for the addition of these inorganic fillers is to reduce the methanol permeability while keeping the ionic conductivity as high as possible. An improvement of the water retention at high temperature and the mechanical properties of the membranes is also usually expected.

Carbon nanotubes are a new class of advanced filler materials with very interesting properties and capacity of improving the mechanical properties of polymer matrices and imparting their electrical conductivity [25-27]. Until very recently, their dispersion within fuel cell polymer membranes was not considered mainly because of risk of short-circuit caused by a non electrically isolated electrolyte. In 2006, Liu et al. demonstrated that this problem could be solved by keeping the content of carbon nanotubes lower than the percolation threshold [28]. The mechanical stability of Nation ${ }^{\circledR}$ membranes was improved by dispersing $1 \mathrm{wt} \%$ CNTs, without affecting the performances of the $\mathrm{H}_{2} / \mathrm{O}_{2}$ fuel cell. However, the method used for the dispersion of CNTs, i.e., a ball-milling method followed by solvent casting, is not appropriate for scaling-up. When methanol fuel-cells are considered, 
the methanol permeability of the Nation ${ }^{\circledR}$ membranes is a problem. Although the cylindrical shape of carbon nanotubes is less suited than the platelet-shape of nanoclays, the effective dispersion of CNTs within Nation ${ }^{\circledR}$ membranes might significantly decrease the methanol permeability, while improving the performances and durability of the fuel-cell. This work relies on the hypothesis that the decrease in the ionic conductivity, which is commonly parallel to a decrease in methanol permeability, could be limited by carbon nanotubes pregrafted with carboxylic acid groups.

\section{EXPERIMENTAL PART}

\section{1. Materials}

The Nation ${ }^{\circledR}$ precursor, i.e., a perfluorosulfonyl fluoride copolymer resin (Nation ${ }^{\circledR}$ R-1100 resin) was supplied by Ion Power Inc., Bear, DE, USA. Commercially available thin multi-walled carbon nanotubes (MWCNT Thin; average outer diameter: $10 \mathrm{~nm}$, purity higher than $95 \mathrm{wt} \%$ ) and MWCNT functionalised by carboxylic acid (com. MWCNT-COOH; Nanocyl®-3101, average outer diameter: 10nm, purity higher than $95 \mathrm{wt} \%$, <4 wt\% $\mathrm{COOH}(0.9 \mathrm{mmol} / \mathrm{g}))$ were supplied by "Nanocyl S. A. " Belgium and produced by Catalytic Carbon Vapour Deposition (CCVD). 4,4'-Azo-bis-(cyanopentanoic acid) was purchased from Aldrich. Carboxylic acid containing MWCNTs (lab. MWCNT-COOH) were also home prepared by addition of 100mg of MWCNT Thin to a solution of $10 \mathrm{~g}$ of 4,4'-azo-bis-(cyanopentanoic acid) in water at $\mathrm{pH} 10$. The solution was deoxidized for 30 min by bubbling of nitrogen. The reaction mixture was heated at $80^{\circ} \mathrm{C}$ and stirred overnight. The nanotubes were filtered and washed several times with water. The modified carbon nanotubes were protonated by immersion in an acidic solution. Montmorillonite with a cationic exchange capacity (CEC) in the 80-95 mequiv. $/ 100 \mathrm{~g}$ range and organomodifled by a hydroxyl containing alkyl ammonium (MMT 30B) was supplied by Southern Clay Products (USA).

\section{2. Membrane preparation}

The Nation ${ }^{\circledR}$ membranes were prepared by melt-mixing of the Nation ${ }^{\circledR}$ precursor with the required amount of carbon nanotubes at $180^{\circ} \mathrm{C}$ in a $5-\mathrm{cm}^{3} \mathrm{DSM}$ microextruder under nitrogen at $200 \mathrm{rpm}$ for $5 \mathrm{~min}$, followed by processing with a laboratory two-roll mill at $200^{\circ} \mathrm{C}$. The sulfonyl fluoride groups were hydrolysed by immersion in a solution of $\mathrm{KOH} /$ water/dimethylsulfoxide $(1.5 / 3.5 / 5)$ at $80^{\circ} \mathrm{C}$ for $2 \mathrm{~h}$, followed by repeated immersion (three times) in a fresh solution of $\mathrm{HNO}_{3}(20 \mathrm{vol} \%)$ for $1 \mathrm{~h}$. Before any characterization, the membranes were pretreated in a conventional manner, i.e., $1 \mathrm{~h}$ in a boiling $5 \% \mathrm{H}_{2} \mathrm{O}_{2}$ aqueous solution, $1 \mathrm{~h}$ in boiling $1 \mathrm{M} \mathrm{H}_{2} \mathrm{SO}_{4}$ solution and repeated washing with Milli Q water (18 M $\Omega)$.

\section{3. Characterization}

MWCNT dispersions within Nation ${ }^{\circledR}$ were observed by transmission electron microscopy PHILIPS M100 at an accelerating voltage of $100 \mathrm{kV}$. Thin sections $(90 \mathrm{~nm})$ were prepared by ultramicrotomy (ULTRACUT E from REICHERT-JUNG) at $-130^{\circ} \mathrm{C}$. Micrographs were analyzed by using the KS 100 (Kontron Imaging System) software.

Thermogravimetric analysis (TGA) was performed under a nitrogen flow $\left(60 \mathrm{~cm}^{3} / \mathrm{min}\right)$ at a heating rate of $20^{\circ} \mathrm{C} / \mathrm{min}$ from room temperature to $600^{\circ} \mathrm{C}$, with a Hi-Res TGA Q500 from TA Instruments.

Methanol permeability was measured with a two-compartment cell filled with an aqueous solution of 1-butanol $(0.2 \mathrm{vol} \%)$. Methanol (8 vol\%) was added in the donating compartment. The methanol concentration in the receiving compartment was measured as a function of time by gas chromatography with 1-butanol as an internal reference. A detailed description of this method was reported elsewhere [21]. Ionic conductivity was measured by impedance spectroscopy at $1 \mathrm{kHz}$ with four platinum probes in contact with the membrane using a frequencyresponse analyzer as detailed elsewhere [21].

Stress-strain curves were recorded at room temperature with an INSTRON tester (model 5566) at $20 \mathrm{~mm} / \mathrm{min}$ tensile speed. The tensile modulus was calculated from the slope in the linear regime at $1 \%$ deformation.

\section{RESULTS AND DISCUSSION}

Mechanical stability and methanol permeability of Nation ${ }^{\circledR}$ are the two main properties that are expected to be improved by dispersion of carbon nanotubes. However, a decrease in ionic conductivity by these nanofillers may not be precluded. In order to restrict this drawback, two kinds of carboxylic acid containing MWCNTs were used, i.e., commercially available nanotubes (com. MWCNT-COOH) and nanotubes home grafted by alkyl radicals bearing a carboxylic acid group (lab. MWCNT-COOH) (Fig. 1) according to a previously reported technique [29]. A commercially available radical polymerization initiator, 4,4'-azo-bis-(4-cyanovaleric acid) (V501), was used, which, upon thermolysis, releases carboxylate containing alkyl radicals. This functionalization method was carried out under very mild conditions which are less harmfull to the nanotubes compared to the conventional method of strong oxidization (conc. $\mathrm{HNO}_{3}$ ) under reflux. The grafting ratio (GR), defined as the 
weight ratio of the grafted radicals to the nanotubes, was determined by TGA after purification of the modified MWCNTs by repeated washing with basic water.

Fig. 1. Schematic grafting of the MWCNTs by carboxylic acid salt.

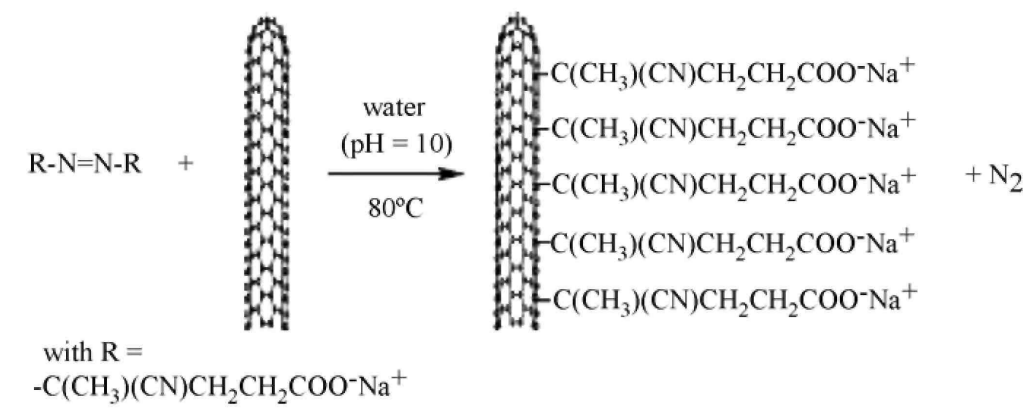

The average GR was $7.5 \mathrm{wt} \%$, which corresponds to a carboxylic group content of $0.6 \mathrm{mmol} / \mathrm{g}$ of MWCNTs. The modified carbon nanotubes were then protonated by immersion in an acidic solution. MWCNTs, com. MWCNT$\mathrm{COOH}$ and lab. MWCNT-COOH, were then dispersed within Nafion ${ }^{\circledR}$ by melt-blending in a $5 \mathrm{~cm}^{3}$ microextruder at $180^{\circ} \mathrm{C}$ for $10 \mathrm{~min}$. However, the clusters formed by the sulfonic acid groups of Nafion ${ }^{\circledR}$ act as crosslinkers and prevent the polymer to be melt-processed below the degradation temperature. Therefore, another dispersion method was implemented, based on a Nafion ${ }^{\circledR}$ precursor, i.e., the sulfonyl fluoride derivative, which does not form clusters and is easily melted at $180^{\circ} \mathrm{C}$. After the membrane formation, the sulfonyl fluoride groups are easily converted into acid by immersion in a solution of $\mathrm{KOH} /$ water/dimethylsulfoxide $(1.5 / 3.5 / 5)$ at $80^{\circ} \mathrm{C}$ for $2 \mathrm{~h}$, followed by repeated immersion (three times) in a fresh solution of $\mathrm{HNO}_{3}(20 \mathrm{vol} \%)$ for lh (Fig. 2).

Fig. 2. Hydrolysis of the Nafion $®$ precursor.

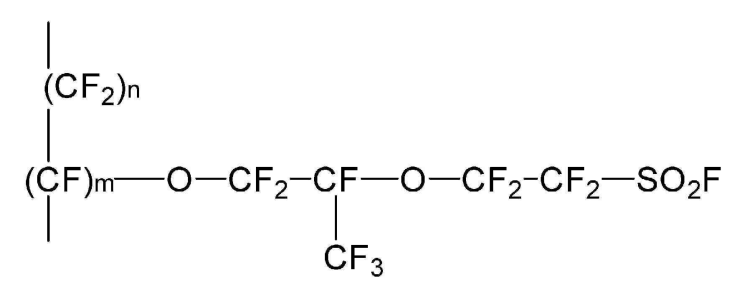

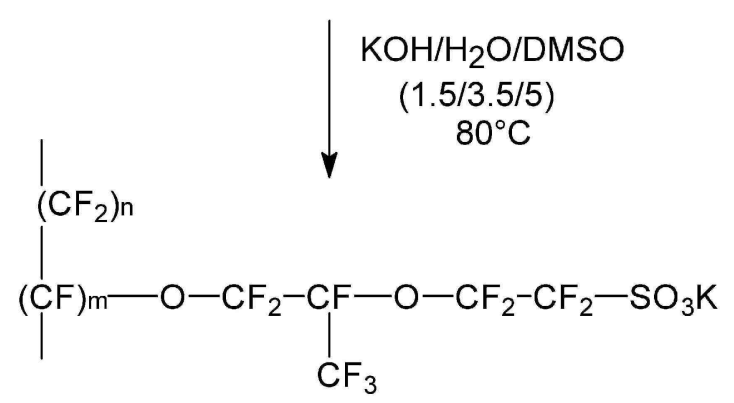

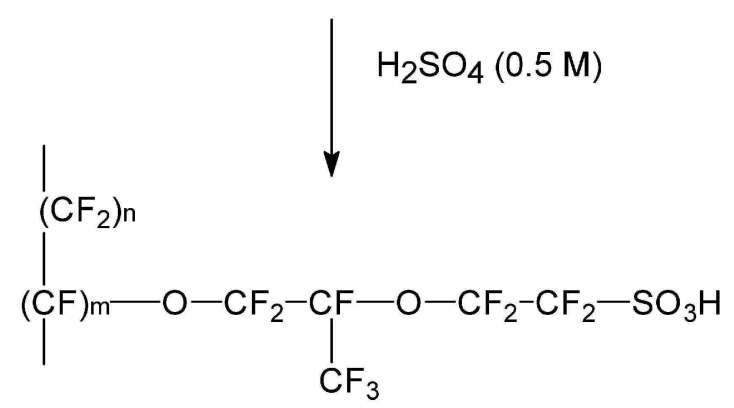


Dispersions of MWCNTs, com. MWCNT-COOH and lab. MWCNT-COOH, were observed by transmission electron microscopy (TEM) as shown in Fig. 3. In each case, the carbon nanotubes were uniformly dispersed as single nanoobjects, no agglomeration being observed whatever the spot probed in the samples. No apparent difference in the dispersion extent of the nanotubes could be observed by TEM. However, the length of the com. MWCNT-COOH was much smaller than the MWCNT Thin, which confirms that these nanotubes are more fragile than the ones prepared by the home-grafting method. Nevertheless, the carbon nanotubes seem to be shortened by the melt-mixing process as testified by the TEM micrographs $(<1 \mu \mathrm{m})$.

In order to avoid any short-circuit in the fuel cell, the membrane should not be electrically conductive, thus, the carbon nanotubes should not percolate. The length and amount of the carbon nanotubes in the membrane should thus be carefully controlled. The electrical conductivity was measured by impedance spectroscopy for the MWCNT-filled membrane in the sulfonyl fluoride form, such that ionic conductivity cannot contribute to the measurement. Table 1 shows that below $2 \mathrm{wt} \%$, the electrical conductivity is lower than the detection limit of the equipment. Above $3 \mathrm{wt} \%$, although significant, the electrical conductivity of the membrane is low $\left(<10^{-3} \mathrm{~S} / \mathrm{cm}\right)$.

Fig. 3. TEM migrigraphs of Nafion ${ }^{\circledR}$ membranes filled with 1 wt\% of (a) MWCNT, (b) lab. MWCNT-COOH and (c) com. MWCNT-COOH.
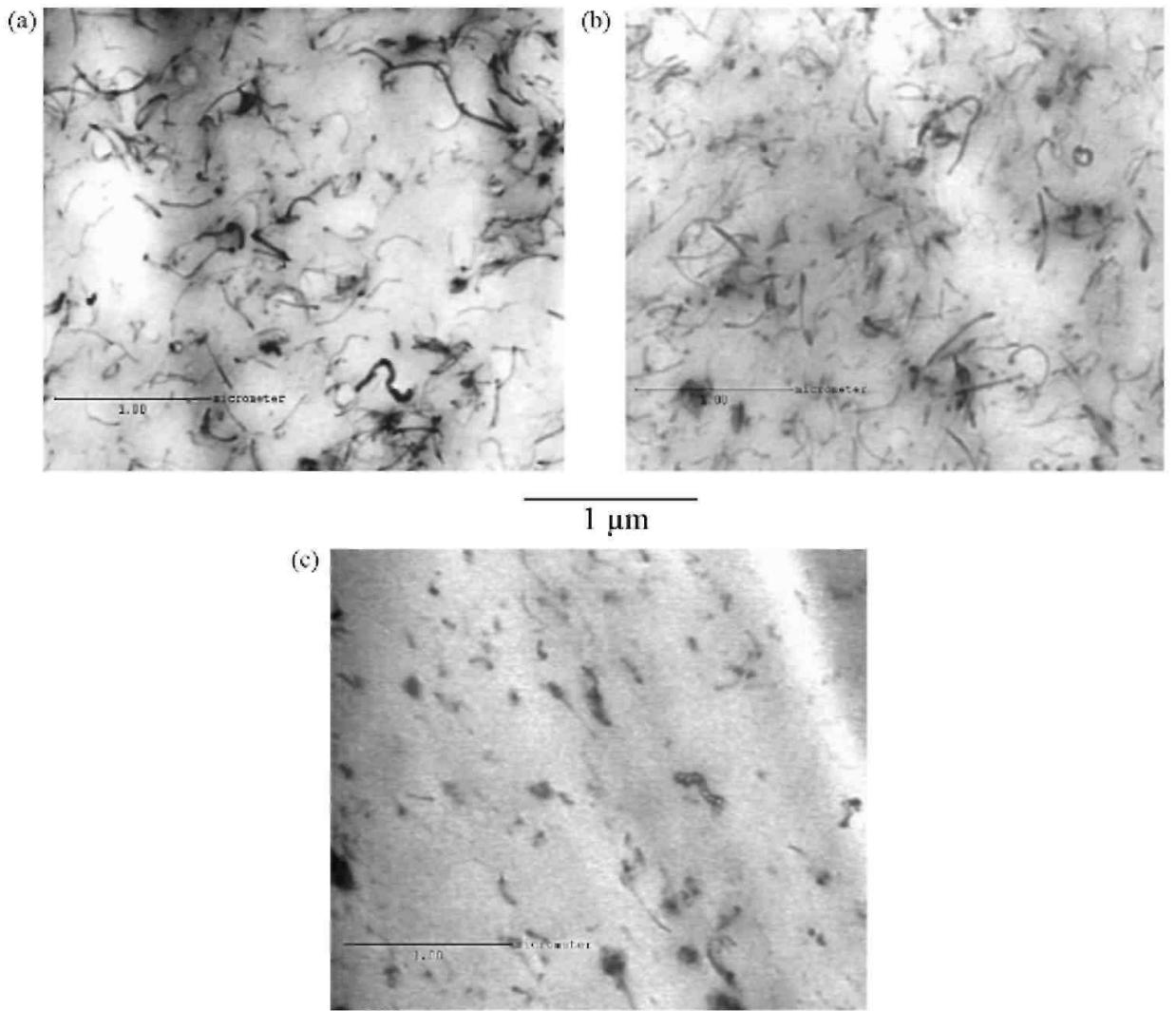

Table 1 : Electrical conductivity of films of the Nafion ${ }^{\circledR}$ precursor filled by MWCNTs

\begin{tabular}{ll}
\hline MWCNT content (wt \%) & Conductivity (S/cm) \\
\hline 0 & $\mathrm{a}$ \\
1 & $\mathrm{a}$ \\
2 & $\mathrm{a}$ \\
3 & $2.82 \times 10^{-6}$ \\
4 & $3.48 \times 10^{-5}$ \\
5 & $4.88 \times 10^{-4}$ \\
\hline
\end{tabular}

${ }^{\mathrm{a}}$ Too low for being measured. 
There is thus no risk of short-circuit during the fuel cell test operation whenever the MWCNT content of the membrane is lower than $2 \mathrm{wt} \%$. The swelling degree of Nafion membranes is poorly affected by the MWCNT, the water uptake being approximately $23.5 \pm 1 \%$ for the membrane before and after filling with 1 and 2 wt $\%$ of each type of MWCNT. The methanol permeability of the Nafion ${ }^{\circledR}$ membranes in the ionic form is reported in Fig. 4. This property is decreased by ca. $60 \%$ when the neat polymer is filled with $2 \mathrm{wt} \%$ of MWCNTs. The same effect was observed upon the polymer addition by organomodified montmorillonite (MMT 30B, Fig. 4) [24].

FIG. 4. Methanol permeability of Nafion $®$ membranes filled with MWCNT, com. MWCNT-COOH, lab. MWCNT-COOH and MMT 3OB, as a function of the filler content (full lines are guides for the eyes).

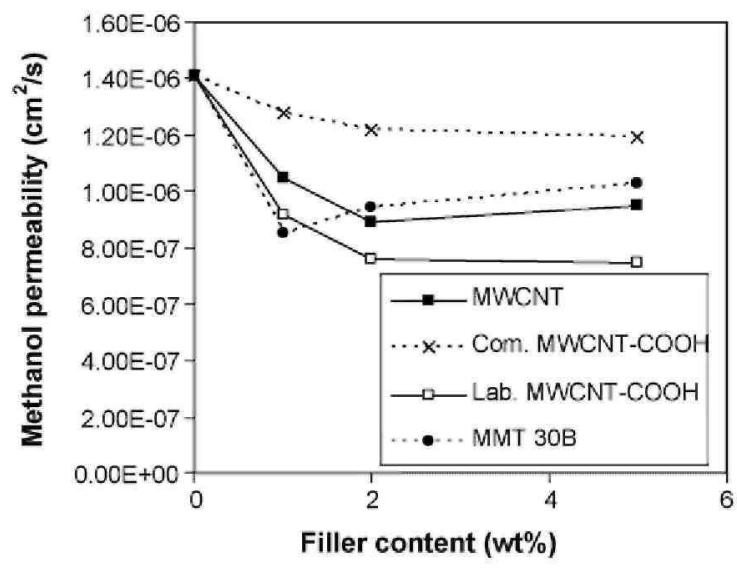

Although fillers are expected to be less effective than the sheet-like fillers in improving the barrier property, the better dispersion of the MWCNTs compared to the layered silicates can account for comparable decrease in methanol permeability. The lab. MWCNT-COOH decreases further the permeability, which may reflect a better dispersion of the nanotubes compared to unfunctionalized MWCNTs. Beyond $2 \mathrm{wt} \%$ filler, the methanol permeability does not decrease anymore, but rather increases slightly with the MWCNT content more likely because of the aggregation of the nanotubes. The influence of com. MWCNT-COOH on methanol permeability is lower than in the two other cases more likely because of the shorter length of these nanotubes. Fig. 5 shows that addition of MWCNTs decreases slightly the ionic conductivity of the Nation ${ }^{\circledR}$ membranes.

Fig. 5. Ionic conductivity of Nafion ${ }^{\circledR}$ membranes filled with MWCNT, com. MWCNT-COOH, lab. MWCNT$\mathrm{COOH}$ and MMT 30B, as a function of the filler content (full lines are guides for the eyes).

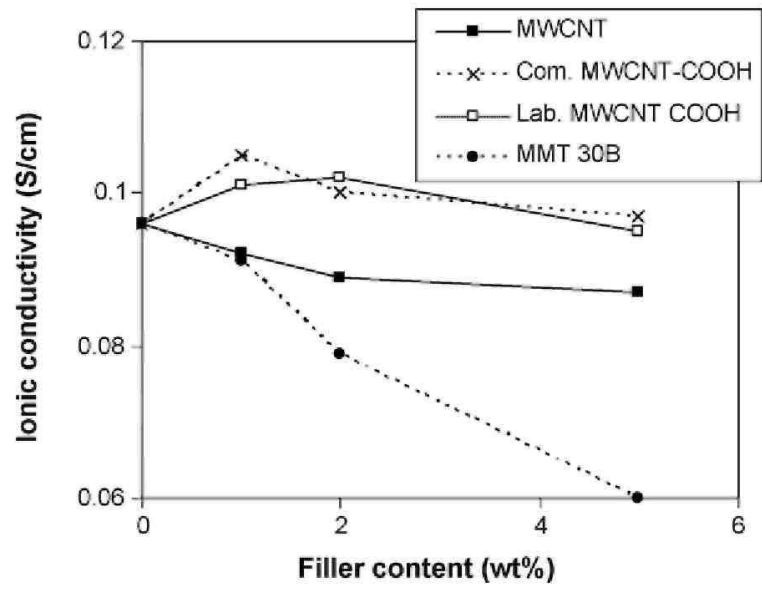

This decrease is very small compared to the effect observed upon addition of montmorillonite (5\% versus $25 \%$ at $2 \mathrm{wt} \%$ filler content) [24]. It is however erased by the grafting of carboxylic acid onto the surface of the MWCNTs. A slight increase is even observed at low filler content. The addition of $2 \mathrm{wt} \%$ of lab. MWNT-COOH increases the ratio between the ionic conductivity and the methanol permeability ( $C / P$ ratio) by a factor 2 , which 
is at least as effective as the addition of silica particles (1.5 times increase) [30-31], a combination of Zirconium oxide and zirconium phosphate (2.3 times increase) [33] and palladium nanoparticles (1.5 times increase) [34]. The effect of the MWCNTs on the mechanical properties of the Nation ${ }^{\circledR}$ membranes has been evaluated by tensile testing at room temperature (Fig. 6).

Fig. 6. Young's modulus of Nafion ${ }^{\circledR}$ membranes filled with MWCNT, com. MWCNT-COOH and lab. MWCNT$\mathrm{COOH}$ as a function of the filler content (full lines are guides for the eyes).

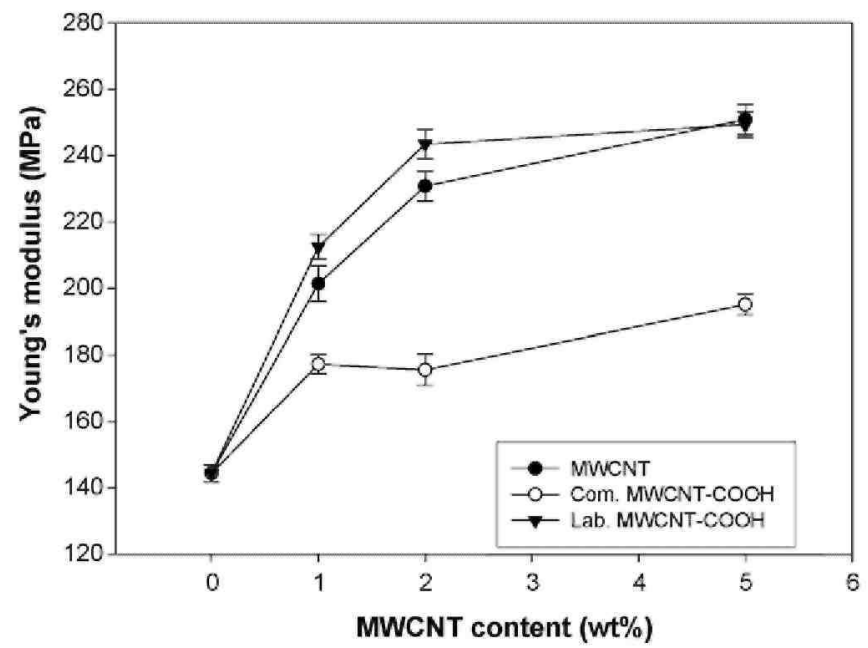

The Young's modulus is increased by $140 \%$ and $160 \%$ for MWCNT contents of 1 and $2 \mathrm{wt} \%$ as compared to pure Nation ${ }^{\circledR}$, respectively. The reinforcing effect of the MWCNT should delay any membrane failure which occurs rapidly when Nafion ${ }^{\circledR}$ is hydrated at temperature higher than $80^{\circ} \mathrm{C}$. The increase in the Young's modulus is slightly higher in case of lab. MWCNT-COOH, consistent with a better dispersion. Again, the shorter length of com. MWCNT-COOH accounts for a lower increase in Young's modulus observed in this case. In each case, the Young's modulus levels off at MWCNT contents exceeding $2 \mathrm{wt} \%$, in relation to the incipient aggregation of the nanotubes.

\section{CONCLUSIONS}

Nafion ${ }^{\circledR}$ membranes were modified by multi-wall carbon nanotubes by a straightforward melt-mixing technique. No electrical conductivity was measured for nanofiller content lower than $2 \mathrm{wt} \%$, such that any risk of shortcircuit was avoided. TEM observations confirmed the effective dispersion of the nanotubes. Consistently, the methanol permeability was significantly decreased whereas only a slight decrease in the ionic conductivity was observed. The well-balanced effect of the nanotubes on the barrier property and the ionic conductivity of Nafion ${ }^{\circledR}$ was even improved by the surface modification of the MWCNTs by carboxylic acid groups. Radical grafting of aliphatic carboxylic acid onto MWCNTs proved to be less deleterious to the length of the nanotubes than the conventional carboxylation by strong oxidizing treatment. Finally, 2 wt\% of MWCNTs was beneficial to the Young's modulus of the membranes, that increased by $160 \%$ as compared to pure Nafion®.

\section{Acknowledgements}

CERM is grateful to the Région Wallonne for financial support in the frame of the "Pile a combustible" program INNOPILE. It is also indebted to the "Belgian Science Policy" for financial support in the frame of the "Interuniversity Attraction Poles Programme (PAI 6/27)". CD is "Chercheur Qualifié" by the FNRS (Belgium).

\section{References}

[1] T. Kobayashi, M. Rikukawa, K. Sanui, N. Ogata, Proton-conducting polymers derived from poly(ether-etherketone) and poly(4phenoxybenzoyl-1, 4-phenylene), Solid State Ionics 106 (1998) 219.

[2] R. W. Kopitzke, C. A. Linkous, H. R. Anderson, G. L. Nelson, Conductivity and water uptake of aromatic-based proton exchange membrane electrolytes, J. Electrochem. Soc. 147 (2000) 1677.

[3] P. Genova-Dimitrova, B. Baradie, D. Foscallo, C. Poinsignon, J. Y. Sanchez, Ionomeric membranes for proton exchange membrane fuel cell (PEMFC): sulfonated polysulfone associated with phosphatoantimonic acid, J. Membr. Sci. 185 (2001) 59.

[4] J. Kerres, W. Cui, S. Reichle, A New sulfonated engineering polymers via the metalation route. I. Sulfonated poly(ether sulfone) PSU Udel via metalation-sulfonation-oxidation, J. Polym. Sci. A 34 (1996) 2421. 
[5] F. Wang, M. Hickner, Y. S. Kim, T. A. Zawodzinski, J. E. McGrath, Direct polymerization of sulfonated poly(arylene ether sulfone) random (statistical) copolymers: candidates for new proton exchange membranes, J. Membr. Sci. 197 (2002) 231.

[6] Y. Yin, J. Fang, Y. Cui, K. Tanaka, H. Kita, K. Okamoto, Synthesis, proton conductivity and methanol permeability of a novel sulfonated polyimide from 3-(2', 4'-diaminophenoxy)propane sulfonic acid, Polymer 44 (2003) 4509.

[7] Y. Woo, S. Y. Oh, Y. S. Kang, B. Jung, Synthesis and characterization of sulfonated polyimide membranes for direct methanol fuel cell, J. Membr. Sci. 220(2003)31.

[8] J. S. Wainright, J. T. Wang, D. Weng, R. F. Savinell, M. Litt, Acid-doped polybenzimidazoles: a new polymer electrolyte, J. Electrochem. Soc. 142 (1995) L121.

[9] X. Glipa, B. Bonnet, B. Mula, D. J. Jones, J. Rozière, Investigation of the conduction properties of phosphoric and sulfuric acid doped polybenzim-idazole, J. Mater. Chem. 9 (1999) 3045

[10] P. Staiti, Proton conductive membranes based on silicotungstic acid/silica and polybenzimidazole, Mater. Lett. 47 (2001) 241.

[11] W. Xu, T. Lu, C. Liu, W. Xing, Low methanol permeable composite Nafion/silica/PWA membranes for low temperature direct methanol fuel cells, Electrochim. Acta 50 (2005) 3280.

[12] PL. Antonucci, A. S. Aricò, P. Cretì, E. Ramunni, V. Antonucci, Investigation of a direct methanol fuel cell based on a composite Nafion ${ }^{\circledR}$-silica electrolyte for high temperature operation, Solid State Ionics 125 (1999) 431.

[13] V. Ramani, H. R. Kunz, J. M. Fenton, Investigation of Nafion®/HPA composite membranes for high temperature/low relative humidity PEMFC operation, J. Membr. Sci. 232 (2004) 31.

[14] Z. G. Shao, H. Xu, M. Li, I. M. Hsing, Hybrid Nafion-inorganic oxides membrane doped with heteropolyacids for high temperature operation of proton exchange membrane fuel cell, Solid State Ionics 177 (2006) 779.

[15] P. Costamagna, C. Yang, A. B. Bocarsly, S. Srinivasan, Nafion 115/zirco-nium phosphate composite membranes for operation of PEMFCs above $100^{\circ} \mathrm{C}$, Electrochim. Acta 47 (2002) 1023

[16] F. Bauer, M. Willert-Porada, Microstructural characterization of Zr-phosphate-Nafion® membranes for direct methanol fuel cell (DMFC) applications, J. Membr. Sci. 233 (2004) 141

[17] C. Yang, S. Srinivasan, A. B. Bocarsly, S. Tulyani, J. B. Benziger, A comparison of physical properties and fuel cell performance of Nafion and zirconium phosphate/Nafion composite membranes, J. Membr. Sci. 237 (2004) 145

[18] D. H. Jung, S. Y. Cho, D. H. Peck, D. R. Shin, J. S. Kim, Preparation and performance of a Nafion®/montmorillonite nanocomposite membrane for direct methanol fuel cell, J. Power Sources 118 (2003) 205.

[19] R. F. Silva, S. Passerini, A. Pozio, Solution-cast Nafion®/montmorillonite composite membrane with low methanol permeability, Electrochim. Acta 50 (2005) 2639.

[20] M. K. Song, S. B. Park, Y. T. Kim, K. H. Kim, S. K. Min, H. W. Rhee, Characterization of polymer-layered silicate nanocomposite membranes for direct methanol fuel cells, Electrochim. Acta 50 (2004) 639.

[21] J. M. Thomassin, C. Pagnoulle, D. Bizzarri, G. Caldarella, A. Germain, R. Jerome, Nation-layered silicate nanocomposite membrane for fuel cell application, e-Polymer 018 (2004).

[22] C. H. Rhee, H. K. Kim, H. Chang, J. S. Lee, Montmorillonite composite: a new concept of electrolyte membrane for direct methanol fuel cells, Chem. Mater. 17 (2005) 1691.

[23] J. M. Thomassin, C. Pagnoulle, G. Caldarella, A. Germain, R. Jerome, Contribution of nanoclays to the barrier properties of a model proton exchange membrane for fuel cell application, J. Membr. Sci. 270 (2006) 50.

[24] J. M. Thomassin, C. Pagnoulle, G. Caldarella, A. Germain, R. Jerome, Impact of acid containing montmorillonite on the properties of Nafion® membranes, Polymer 46 (2005) 11389

[25] T. McNallya, P. Potschke, P. Halley, M. Murphy, D. Martin, S. E. Bell, G. P. Brennan, D. Bein, P. Lemoine, J. P. Quinn, Polyethylene multiwalled carbon nanotube composites, Polymer 46 (2005) 8222.

[26] F. Du, J. E. Fischer, K. I. Winey, Coagulation method for preparing single-walled carbon nanotube/poly(methyl methacrylate) composites and their modulus, electrical conductivity, and thermal stability, J. Polm. Sci., B 41 (2003)3333.

[27] F. Du, R. C. Scogna, W. Zhou, S. Brand, J. E. Fischer, K. I. Winey, Nanotube networks in polymer nanocomposites: rheology and electrical conductivity, Macromolecules 37 (2004) 9048

[28] Y. H. Liu, B. Yi, Z. G. Shao, D. Xing, H. Zhang, Carbon nanotubes reinforced nation composite membrane for fuel cell applications electrochem, Solid-State Lett. 9 (2006) A356.

[29] F. Stoffelbach, A. Aqil, C. Jerome, R. Jerome, C. Detrembleur, An easy and economically viable route for the decoration of carbon nanotubes by magnetite nanoparticles, and their orientation in a magnetic field, Chem. Commun. 36 (2005) 4532.

[30] N. Miyake, J. S. Wainright, R. F. Savinell, Evaluation of a sol-gel derived Nafion/silica hybrid membrane for proton electrolyte membrane fuel cell applications. I. Proton conductivity and water content, J. Electrochem. Soc. 148 (2001) A898

[31] N. Miyake, J. S. Wainright, R. F. Savinell, Evaluation of a sol-gel derived Nafion/silica hybrid membrane for polymer electrolyte membrane fuel cell applications. II. Methanol uptake and methanol permeability, J. Electrochem. Soc. 148 (2001) A905.

[33] B. Ruffmann, H. Silva, B. Schulte, S. P. Nunes, Organic/inorganic composite membranes for application in DMFC, Solid State Ionics $162-163(2003) 269$.

[34] Y. J. Kim, W. C. Choi, S. I. Woo, W. H. Hong, Evaluation of a palladinized Nation ${ }^{\mathrm{TM}}$ for direct methanol fuel cell application, Electrochim. Acta 49 (2004) 3227. 